\title{
32. REGIONAL ASPECTS OF DEEP SEA DRILLING IN THE WESTERN NORTH ATLANTIC
}

\author{
J. I. Ewing ${ }^{1}$, Lamont-Doherty Geological Observatory, \\ Columbia University, Palisades, New York and \\ C. H. Hollister ${ }^{2}$, Woods Hole Oceanographic Institution, Woods Hole, Massachusetts
}

\section{INTRODUCTION}

The holes drilled during Leg 11 can be grouped naturally into three geographical areas: those in the vicinity of Cat Gap, those on the Blake-Bahama Outer Ridge, and those on the continental rise and slope southeast of New York. Site 98 in the Northeast Providence Channel is in a category by itself and is dealt with separately (F. Paulus, this volume). In each of the three areas the specific goals for drilling promised to provide significant facts about the development and history of the Atlantic Ocean. We were very fortunate to have had relatively good bathymetric charts, many seismic profiler sections and piston cores, and data from drilling during Legs 1 and 2. The locations of the holes are shown in Figure 1; and the major stratigraphic results are summarized in Figure 2.

\section{CAT GAP AREA}

Special attention was focused on the southwestern region of the Hatteras Abyssal Plain several years ago when some of the earliest seismic profiler traverses showed that reflecting interfaces that are deeply buried in most parts of the North Atlantic are exposed at the sea floor near Cat Gap. The older strata sampled by piston coring range in age from Late Cretaceous near Horizon A to Barremian near Horizon $\beta$. (Ewing et al., 1966; Saito et al., 1966; Windisch et al., 1968; Habib, 1970).

During the coring program that produced these samples, a large quantity of seismic data was accumulated, and on the basis of these investigations two holes (Holes 4 and 5) were drilled in the area during Leg 1. Subsequently, an additional survey was conducted by $\mathrm{R} / \mathrm{V}$ Vema, and three additional holes were drilled during Leg 11. Data from the Vema survey, along with some of the earlier recorded data, are presented by $\mathrm{T}$. Aitken (this volume).

\footnotetext{
${ }^{1}$ Lamont-Doherty Geological Observatory Contribution No. 1728.

${ }^{2}$ Woods Hole Oceanographic Institution Contribution No. 2758.
}

The five holes drilled in this area are shown in relationship to the regional physiography, lithology, and seismic stratigraphy in the block diagrams of Figures 3 and 4 . It is emphasized that these are sketches. Figure 5 shows the section lines relative to the bathymetry. Hole 99 was drilled on a slightly raised step at the foot of the Bahama escarpment, Holes 4, 5 and 100 were drilled in the deep basin, and Hole 101 was drilled in the large sediment pile at the lower end of the southwestern Blake-Bahama Ridge.

\section{Basalt (Horizon B)}

The deepest unit penetrated is basalt, which correlates well with seismic Horizon B. Although it was reached only in Hole 100, the numerous seismic profiles provide good areal control on the depth to this layer. The top of the basalt (acoustic basement) is anomalously smooth in the western margin of the North Atlantic, so much smoother than it is in other parts of the basin that there had been some question as to whether it might be hard sedimentary rock instead of basalt. Whether or not other sedimentary layers are buried under the basalt will probably be debated for some time, but it is noteworthy that the basalt recovered has a chilled upper contact and had not baked the overlying sediment; hence, it is apparently extrusive, rather than intrusive.

Although the basement is regionally smooth in the Cat Gap area, there are a few seamounts or ridges. The ridge between Hole 99 and Hole 4 (Figure 3) is well mapped and is almost perfectly linear for at least 60 kilometers southeast of San Salvador Bank. Farther toward the southeast it changes to a buried scarp, but probably continues for 100 kilometers or more as a distinct feature approximately parallel to the Bahama scarp. This ridge is probably basalt but, to our knowledge, has not been proven so. The line of small seamounts between $24^{\circ}$ and $25^{\circ} \mathrm{N}$ and $72^{\circ}$ and $74^{\circ} \mathrm{W}$ is another indication of structural lineation along this trend. The small ridge between Hole 100 and Hole 5 (Figure 4) is about 40 to 50 kilometers in length and trends slightly west of north. Perhaps coincidentally, it seems to follow a lithification boundary in the overlying sediment layer. More will be said about this in the following section. 


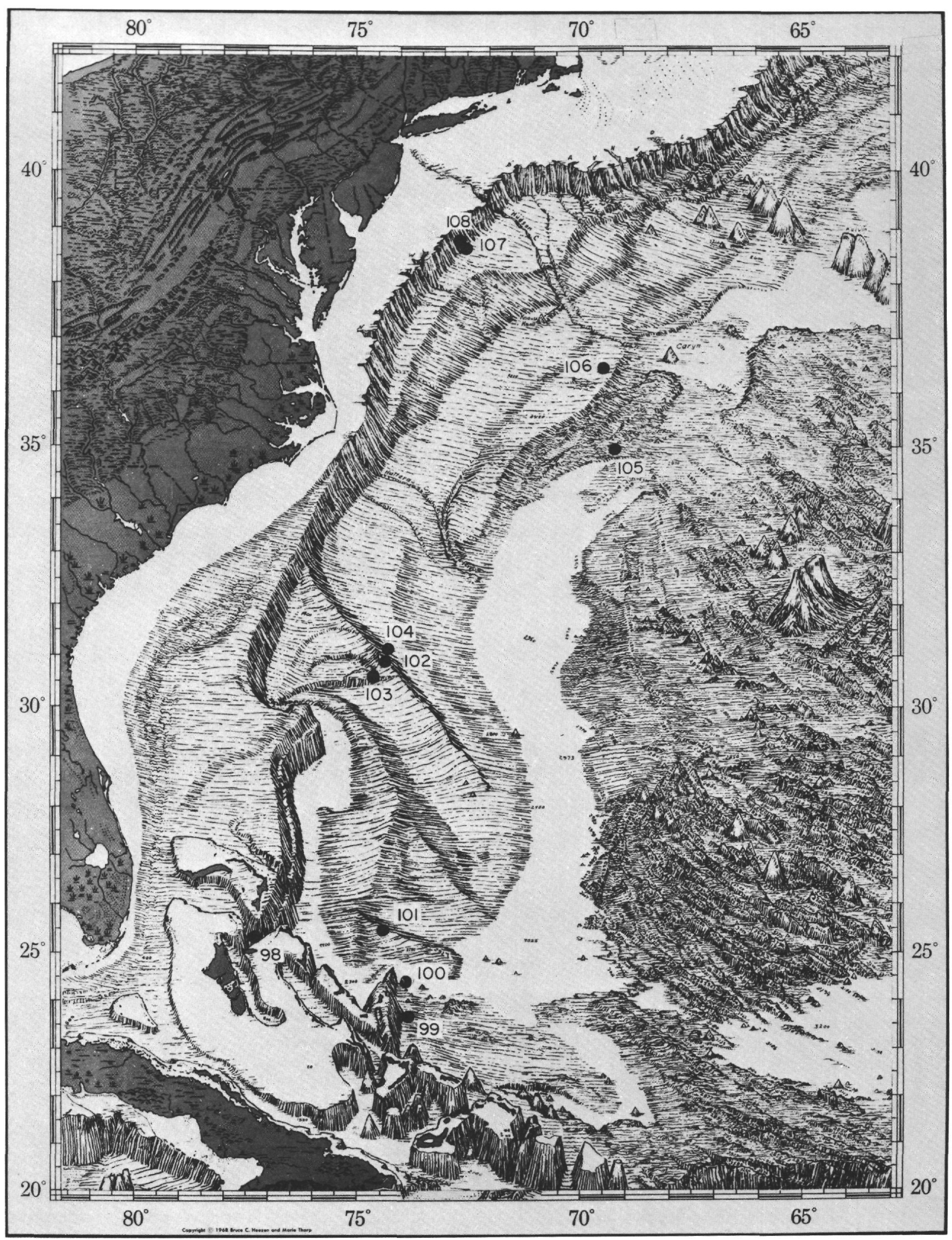

Figure 1. Physiographic diagram of a portion of the western North Atlantic (Heezen and Tharp, 1968) with locations of Leg 11 drilling sites. 


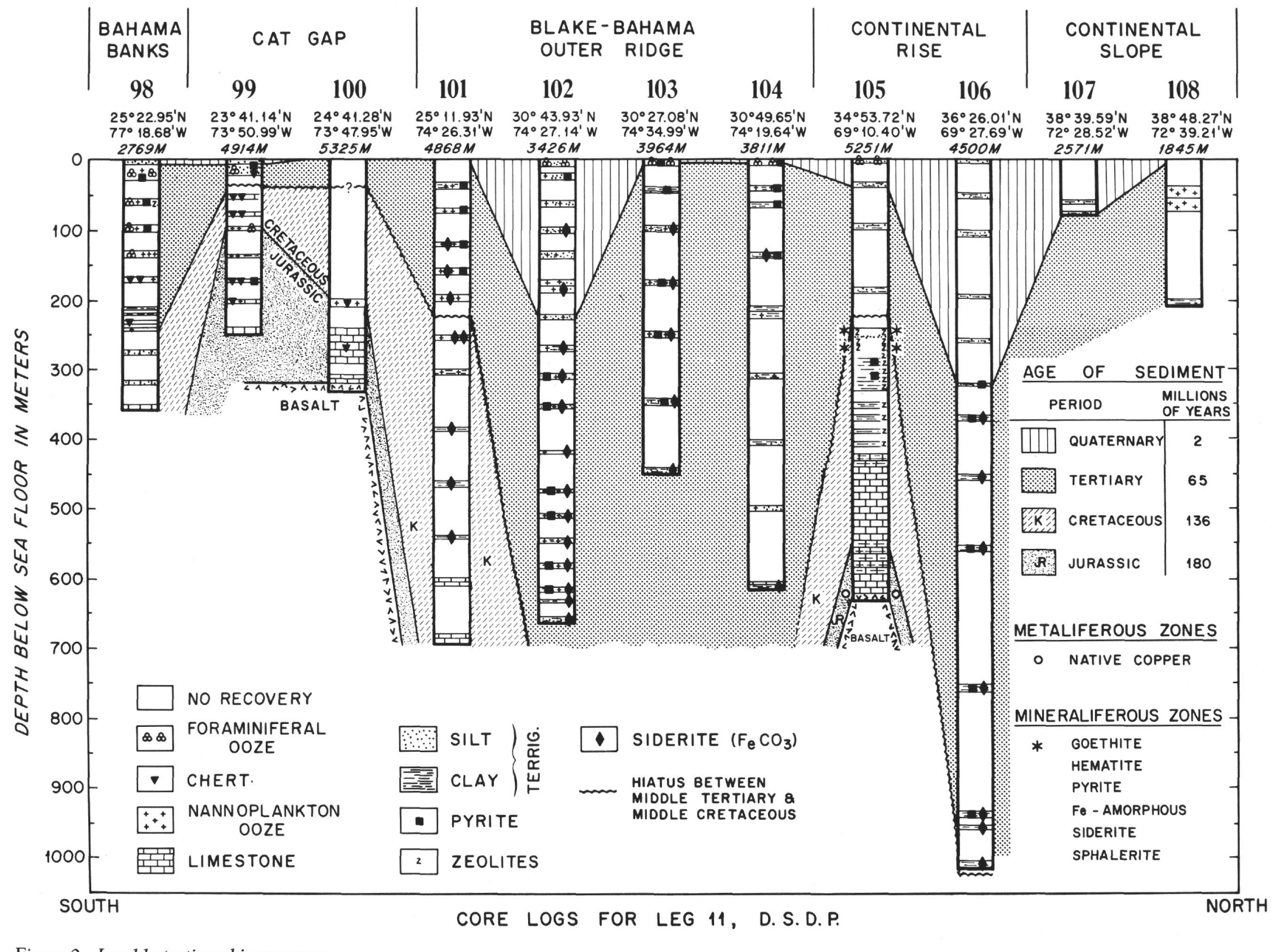

Figure 2. Leg 11 stratigraphic summary. 


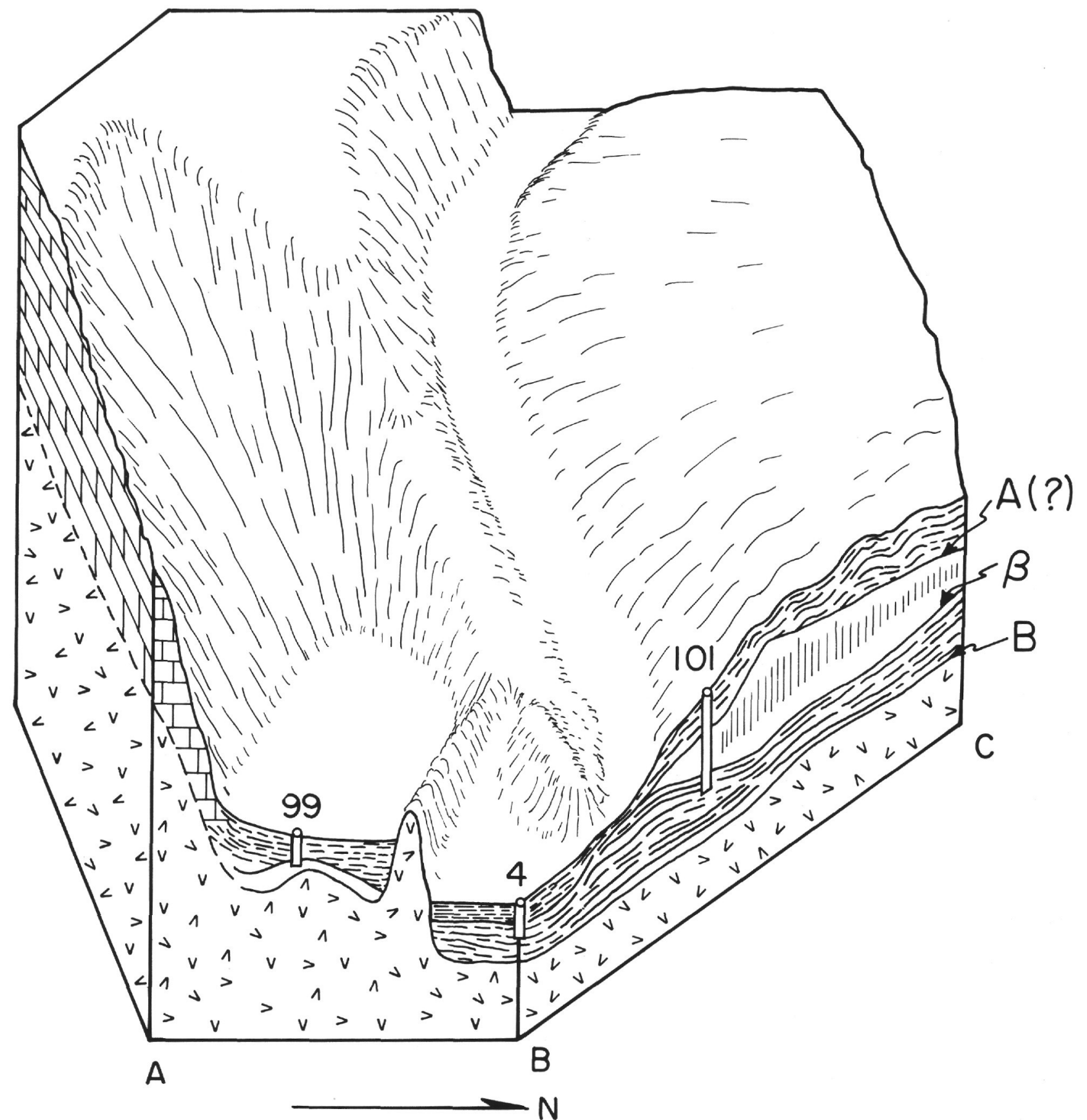

Figure 3. Sketch of the Cat Gap area showing the relationships between physiography, stratigraphic units, and seismic reflectors. Hole depths at Sites 99, 4 and 101 are 248, 259 and 691 meters, respectively. Principal units are: basalt (checked); Neocomian and Late Jurassic limestone, chalk and ooze ( $\beta$-B); Early Cretaceous dark clay (A- $\beta$ ); Late Cretaceous and Tertiary turbidites (post- $\beta$ at Hole 4); and, Late Tertiary hemipelagic mud (post- $A$ at Hole 101). The post-Neocomian section at Hole 99 is less than 50 meters thick and Bis apparently obscured by reverberation.

Late Jurassic and Neocomian Limestones and Chalk (Horizon $\beta$-Horizon B)

The lithologic unit overlying the basalt appears in profiler records in most of this area as a highlystratified section whose average thickness corresponds to about 0.3 second reflection time. In the discussion that follows we will refer to the top of this stratified zone as Horizon $\beta$, and to the interval between it and Horizon $\mathrm{B}$ as the Horizon $\beta$-B section. In some places this section is divided into an upper and a lower 


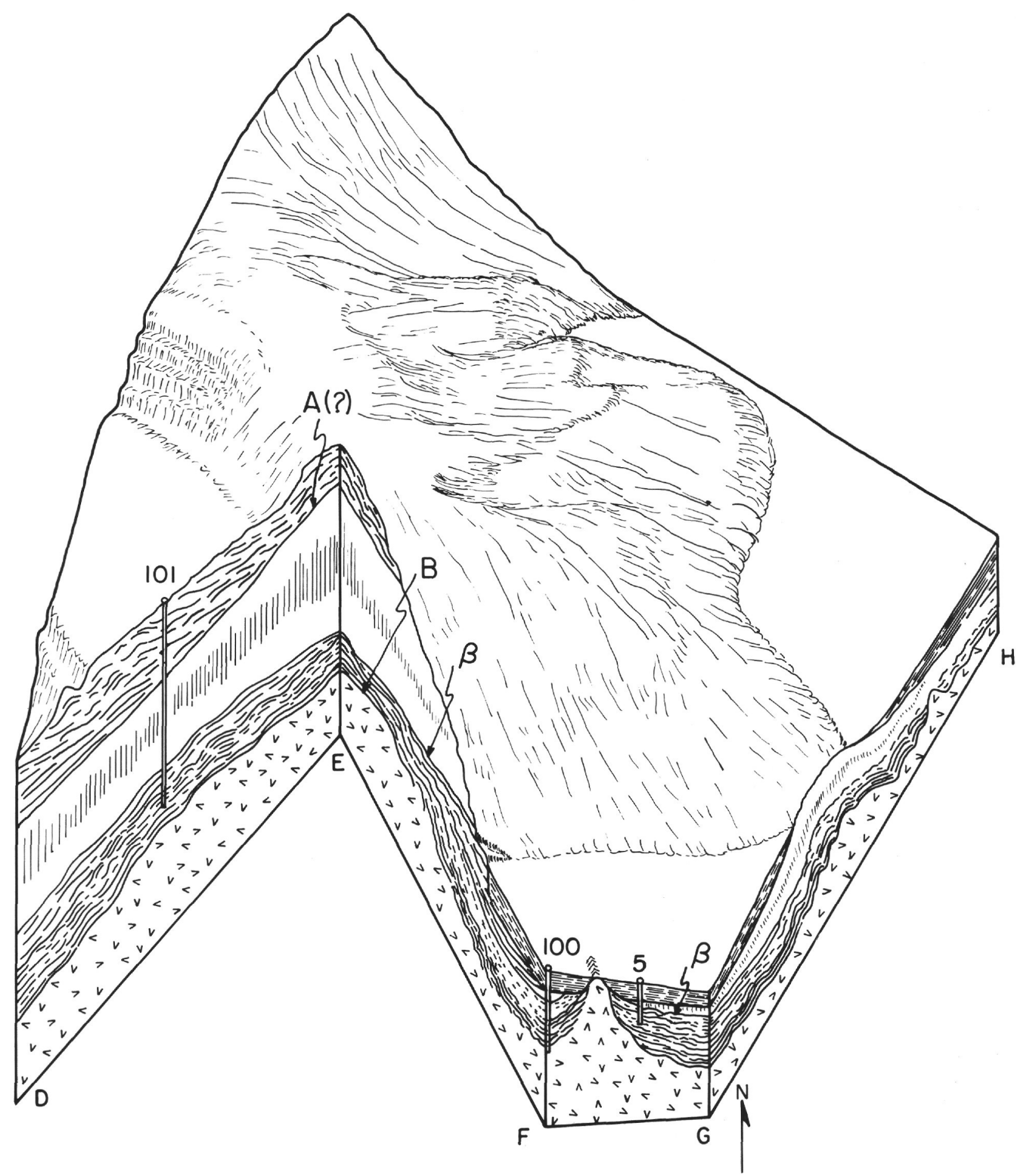

Figure 4. Sketch of the physiography, stratigraphy, and seismic structure drawn from the data of Holes 101 , 100 and 5, and from seismic profiler records. Hole depths at these three sites are 691, 331 and 279 meters, respectively. Principal units are: basalt (checked); Neocomian and Late Jurassic limestone, chalk, and ooze ( $\beta$ - $B$ ); Early Cretaceous dark clay (A- $\beta)$; Late Cretaceous and Tertiary turbidites (upper stratified layer at Sites 5 and 100); and, Late Tertiary hemipelagic mud (post-A at Site 101). The highly stratified upper beds at the northeast corner of the diagram, also shown in Figure 6, are those from which Late Cretaceous turbidites were recovered in piston cores (Ewing et al., 1966b). 
stratified (reflective) zone, and there is usually a relatively unstratified zone near the base of the section. Over broad areas, Horizons $\beta$ and B are approximately conformable, but there are places, for example, between Holes 100 and 101, where they are strongly nonconformable. Similarly, the reflectivity of the various levels of the $\beta$-B section changes very little over large distances in much of the western margin of the basin, but distinct changes in reflectivity are observed in the Cat Gap region. Generally speaking, north and east of the small ridge that lies between Holes 5 and 100 , the $\beta$ and $\mathrm{B}$ reflectors are distinct; south and west of the ridge they are weak. In some places the upper part of the $\beta$-B section apparently has been removed by erosion and replaced by flat-lying, highly stratified beds that probably include some resedimented material.

Ewing et al. (1969) tentatively identified Horizon $\beta$ with a mid-Cenomanian unconformity, but their publication preceded the Vema site survey, and good seismic data were not then available at the location of Hole 5. Because of the weakness of the reflectors west of the ridge, the data from Hole 4 do not give a definite age for the top of the $\beta$-B section. Although no cores were taken in the upper 200 meters of section at Hole 100 , the top of the $\beta$-B section could not be sampled in any case as it appears to have been rather deeply eroded in this area. At Holes 5 and 101, Horizon $\beta$ is very distinct, and we can confidently correlate it with the top of a layer of chalks and limestones. With the additional data now available, particularly at Site 101, we are convinced that the reflector corresponds to the top of the Neocomian limestone sequence. The sampling intervals and available fossils do not permit an exact age determination, but the limestones apparently extend into the Hauterivian/Barremian.

Hole 100 was the only hole in the Cat Gap area to penetrate the entire sedimentary section. In addition to providing an age of the base of the $\beta$-B section (Oxfordian or possibly Callovian), this hole was useful in helping to clarify the nature of the $\beta$-B reflectors. Except when chert layers were encountered, drilling progressed smoothly until a hard layer that correlates with a prominent reflector near the base of the $\beta$-B section was reached. This reflector corresponded to late Jurassic hard limestones. Hole 99 provided similar evidence in that no prominent reflectors were observed except near the base of the section. The average rate of penetration decreased noticeably in the corresponding interval, and the material encountered was hard limestone. Thus, it seems that in a layer that is principally carbonate, the degree of lithification mainly determines the reflectivity of the $\beta$-B reflectors. The upper part of the layer is of Neocomian age and apparently contains hard limestones in most of the western part of the ocean. However, in the Cat Gap region where the most severe erosion has occurred, carbonates of the same age (and older) have remained unlithified. This might suggest that a substantial overburden is a significant factor in the lithification process and that erosion has been continuous enough in some parts of the area that the $\beta$-B section has not been buried deeply enough to produce lithification except in its lower part. In a few places a very strong $\beta$ reflector rises almost to the sea floor, but in these places a thick sedimentary cover may have existed, allowing lithification of the $\beta$ beds, but has subsequently been eroded away.

Aside from these major lateral variations in reflectivity and lithification, there is also some tendency for individual reflectors to fade and reappear over distances of a few kilometers or tens of kilometers. This effect is probably due to lateral variations in lithification on a local scale. If the reflectors are mainly the result of lithification, they can be present at different stratigraphic levels in the section; Horizon $\beta$ which marks the top of the reflective zone must then be considered as of somewhat variable age. However, the existing data strongly suggest that the horizon corresponds to a distinct change from primarily pelagic carbonate deposition to deposition of carbonaceous dark clays, and therefore marks an important change in the depositional environment of the entire ocean. If this is so, the horizon could not be strongly timetransgressive.

The lower surface of the $\beta$-B section becomes younger toward the east as the layer pinches out against basement. It can be traced approximately to the longitude of Bermuda which implies a crustal age there of about 120 million years. This is in general agreement with the age determined by Pitman and Talwani (in press) from interpolation-assuming a constant spreading rate-between the age measured at Hole 105 and the age of Magnetic Anomaly 32.

\section{Early Cretaceous Dark Clay}

This layer corresponds to the unstratified zone above $\beta$ in the diagrams of Figures 3 and 4. It consists mainly of dark clays containing a substantial amount of carbonaceous material, and was apparently deposited in a stagnant environment. A layer of similar age and lithology was well-sampled in the northern part of the basin at Hole 105, so we judge the layer to be present over most of the older part of the North American Basin. Some samples of the dark clay, ranging in age from Cenomanian to Aptian-Albian, had previously been obtained by piston coring in places where Horizon $\beta$ rises close to the sea floor (Windisch et al., 1968; Habib, 1970). The dark clay layer varies greatly in thickness in the Cat Gap region. It is probably missing entirely at Holes 99 and 100 , is between 50 and 100 meters thick at Holes 4 and 5, and is at least 
500 meters thick north and west of Hole 101. In the latter region it forms the major part of the thick mound of sediment that lies between $25^{\circ}$ and $26^{\circ} \mathrm{N}$ latitude and $73.5^{\circ}$ and $75.5^{\circ} \mathrm{W}$ longitude (Figure 5). The western end of this mound tends to coalesce with the southwestern branch of the Blake-Bahama Ridge system, but structurally it is entirely separate. The mound is primarily an Early Cretaceous accumulation, while the ridge system is primarily a Middle/Late Tertiary feature.

The mound-like structure of the dark clay layers near Site 101 suggests that the depositional environment was not entirely quiescent but permitted some preferential accumulation. Subsequent erosion, of which there is ample evidence in Cat Gap, may have reshaped the original deposit into its present form.

In the vicinity of Hole 101 the upper boundary of the dark clay layer is represented by a very prominent reflector labeled $\mathrm{A}($ ?), which appears to be either a continuation of the Middle Eocene Horizon A cored at Sites 6 and 7 or an erosional or nondepositional unconformity with which Horizon A merges. At Holes 4 and 5, the upper boundary corresponds approximately to the base of the Tertiary and Late Cretaceous turbidites described by Ewing et al. (1969).

\section{Late Cretaceous and Early Tertiary}

Many of the holes drilled near the western margin of the Atlantic have produced evidence of very slow deposition or of erosion during the Late Cretaceous and Early Tertiary. At Site 99 the sediment age changed from Middle Pliocene to Hauterivian in an unsampled interval between 21 and 42 meters below bottom, so the Late Cretaceous and Early Tertiary section is probably missing there. A similar situation exists at Site 101 where cored sediments slightly below reflector $\mathrm{A}($ ?) were of Albian age and those 40 meters above were of Middle Miocene age. The data from Holes 4 and 5 show evidence of a mid-Cenomanian unconformity overlain by Late Cretaceous and Early Tertiary turbidites in which there apparently are significant gaps. Ewing et al. (1969) interpreted this to mean that the Cat Gap area has been swept repeatedly by turbidity currents since Early Cretaceous time.

Further evidence for turbidity current activity during the Late Cretaceous is provided by the profiler section of Figure $6 \mathrm{a}$. The unstratified mound is the seismic equivalent of the black clay layer, and the stratified beds that onlap its flanks are the Upper Cretaceous turbidites sampled by piston cores in the early investigation of Horizon A (Ewing et al., 1966; Saito et al., 1966). Where it is not covered by turbidites, the dark clay is apparently covered by a few tens of meters of younger unfossiliferous red clay. Several piston cores have been taken from various parts of the mound and none recovered the dark clay. The turbidites are present under a large area of the southwestern region of the Hatteras abyssal plain and their distribution is quite consistent with the suggestion that at least part of them have reached the plain via Cat Gap. In the area covered by the map of Figure 5, the turbidites are largely confined to the region enclosed by the 2900 -fathom isobath but they are also thick in the embayment that separates the dark clay mound from the southern end of the Blake Ridge. This pattern suggests that some of these turbidites flowed to the basin north of the dark clay mound as well as through Cat Gap. The northern passage was dammed later by the encroachment of the southwest branch of the Blake-Bahama Ridge onto the black clay mound; this also partially blocked the original Cat Gap, but a somewhat more restricted passage at the base of the Bahama scarp has been maintained.

The pattern of reflectors in the turbidite sequence indicates that they are prograded toward the east. From the results of piston coring in the vicinity of records shown in Figure 6, we know that the upper part of the sequence is of Late Cretaceous (Maestrichtian) age, but toward the east there appear to be younger, onlapping beds which might well be of Early Tertiary age.

Slow accumulation during the Late Cretaceous and Early Tertiary was apparent in the results from the northern part of the basin (Hole 105), as well as from the Cat Gap region, which suggests that conditions responsible for it were not local but may have affected the entire western margin of the basin. Because of an insufficient number of datable samples, it is not clear how much Late Cretaceous or Early Tertiary is missing in other parts of the basin. The data indicate up to 200 meters of Eocene at Hole 6 (Ewing et al., 1969), 240 meters of Eocene-Late Cretaceous at Hole 28 (Bader et al., 1970), and more than 350 meters of Eocene-Late Cretaceous at Hole 10 (Peterson et al., 1970), but hiatuses are not precluded. Although some of the sediment missing from the marginal area was probably removed by erosion and redeposited in the central basin, for example, the Late Cretaceous fossils found in Eocene turbidites in Hole 6 (Ewing et al., 1969), sediment accumulation may have been retarded over the entire basin during part of the Early Tertiary. Data from the Central Basin of the Pacific (Winterer et al., 1970) indicate that this phenomenon may have been of world-wide extent.

The results from Holes 101, 105 and 106 indicate that sediment accumulation in the marginal region increased strikingly at about the end of the Early Miocene. Whether this influx of terrestrially-derived sediment resulted from a significant increase in the supply of detrital material, or a change in currents or other environmental conditions is not certain, but there is no 


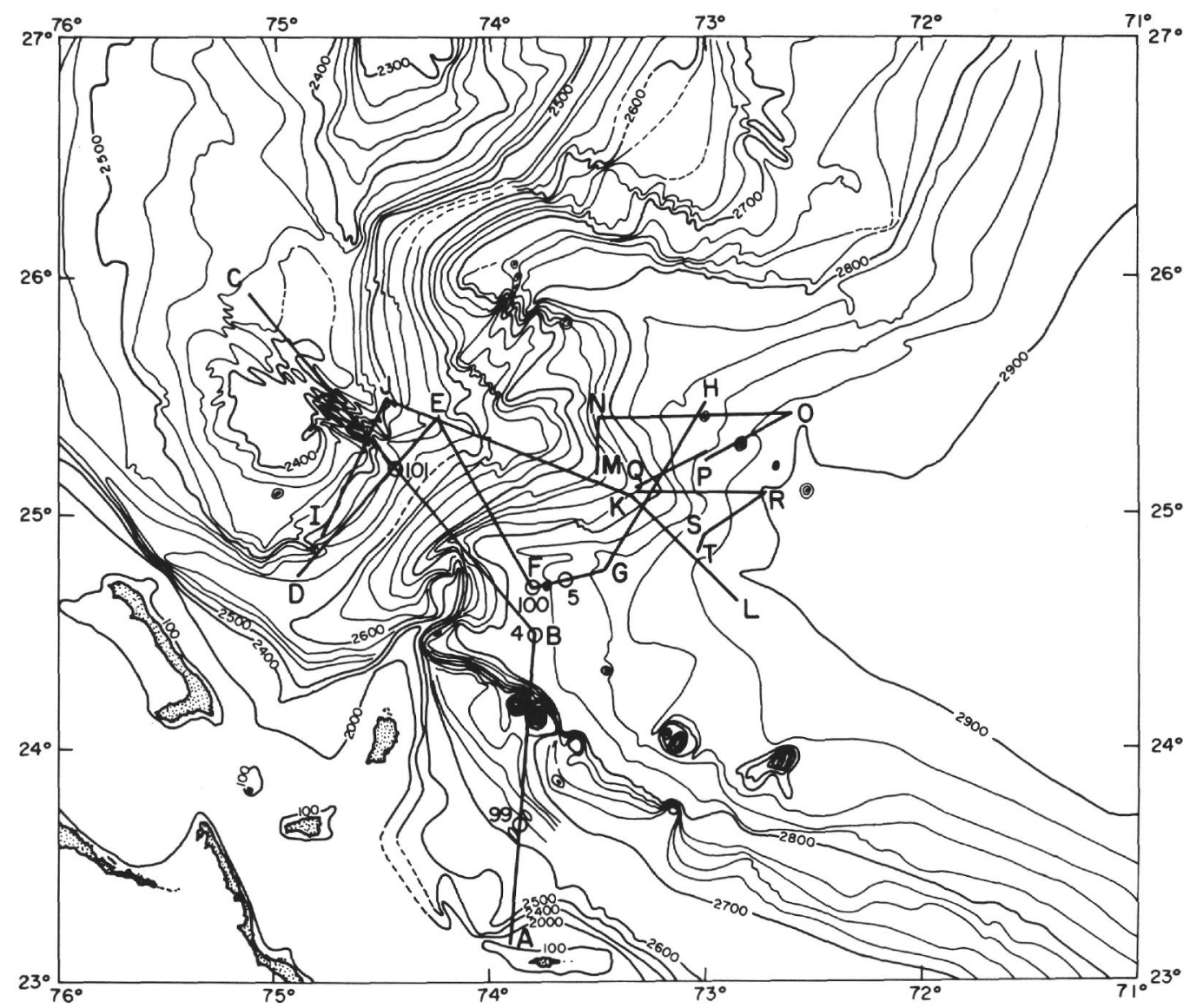

Figure 5. Bathymetry of the Cat Gap region showing locations of the drill sites and of the sections illustrated in Figures 3, 4 and 6. Contours are in fathoms.

doubt that it corresponds to a major change in the depositional regime along the western margin of the basin.

\section{Tertiary and Quaternary (Sea Floor-Horizon A)}

Hole 101 was the only hole of those in the Cat Gap region to penetrate a substantial section of Tertiary sediment, and most of this is of Miocene and younger age (Figure 2). The 200-meter Tertiary section sampled in five cores at this hole consists of hemipelagic mud which, judging by its appearance in seismic profiler records, was deposited under the influence of southward-flowing bottom currents. Mineralogical data also suggest a northern source for these sediments (Lancelot et al., this volume). It is most unfortunate that we did not completely sample the interval that includes the reflector tentatively identified as Horizon A; this presumably would have shed more light on the nature and age of the reflector itself and on the depositional conditions during the transition from the long period of slow accumulation or erosion to rapid deposition of hemipelagic mud.

\section{BLAKE-BAHAMA OUTER RIDGE}

Geologists and geophysicists have speculated for many years about the origin and geologic history of the Blake-Bahama Outer Ridge system, a large accumulation of sediments lying on the horizontal seismic reflector Horizon A (Ewing and Ewing, 1964). This widespread seismic reflector or zone of reflectors corresponds approximately to a zone of silicified beds of early to middle Eocene age in much of the North Atlantic. However, along the continental margins it appears to represent an anomalously thin section or perhaps a hiatus between the Early to Middle Cretaceous and the early to middle Tertiary (see report for Sites 101 and 105).

The suggestion has been made that the form of the Blake-Bahama Outer Ridge results from "diapirism and gravity tectonics" (Andrews, 1967). Others have proposed that it is a sedimentary drift constructed of sediment transported along the sea floor by bottom currents (Heezen and Hollister, 1964; Ewing and Thorndike, 1965; Markl et al., 1970). 

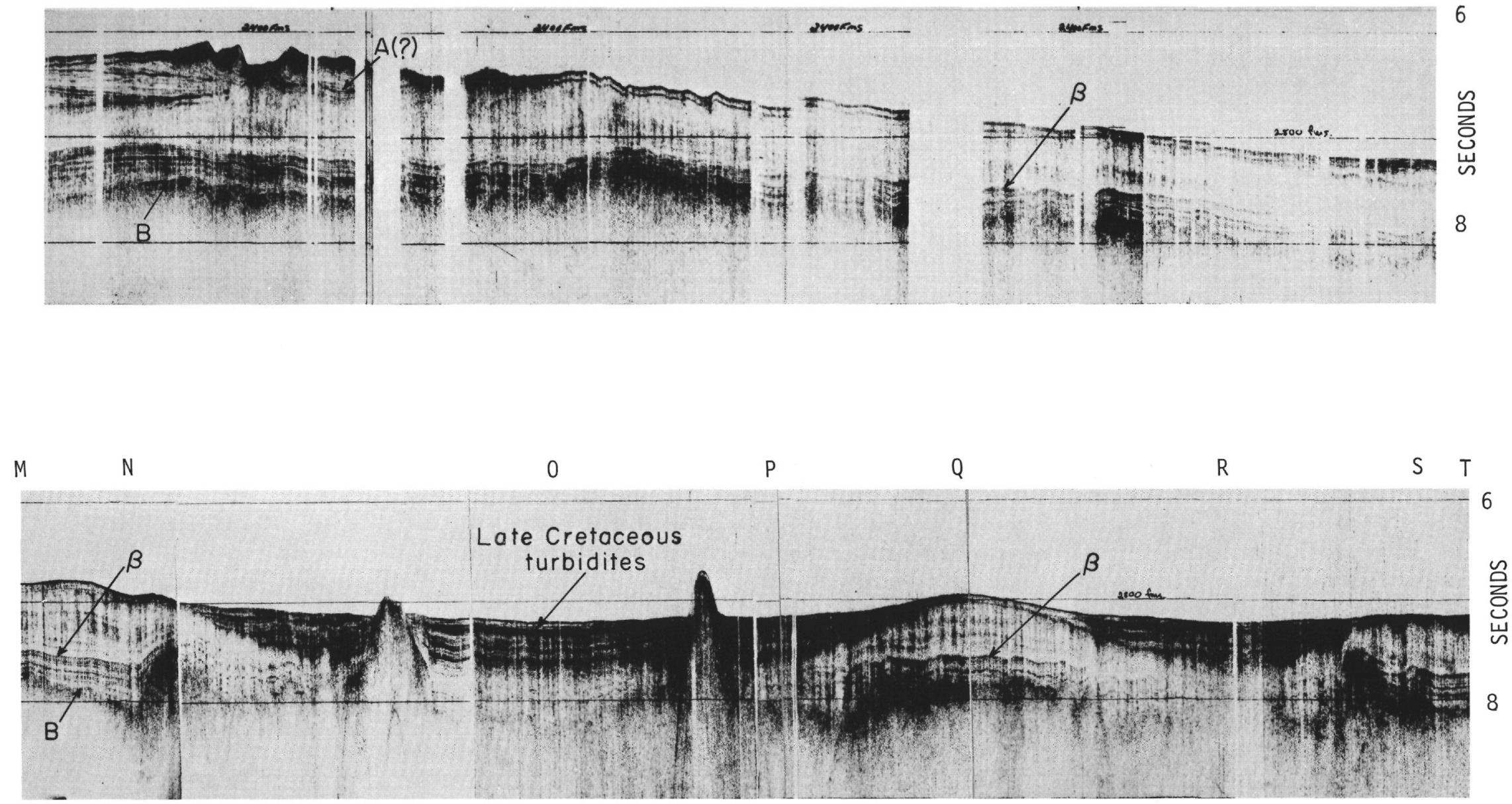

Figure 6. Seismic profiler sections from cruise Vema-21. Track lines are shown in Figure 5. Vertical exaggeration is 25X. 
The source of the sediment making up the ridge has also been a controversial subject. Ewing et al. (1966) have suggested that the Blake Plateau, which has suffered serious erosion near the head of the ridge, is the principal source, while Heezen et al. (1966) have contended that the main source is the continental margins to the north. Bryan (1970) and Markl et al. (1970) proposed a scheme in which both sources were called upon to initiate the development of the ridge, but agreed with Heezen and Hollister (1964) that the southward-flowing boundary current had the principal effect on its later development. The principal objective of the three ridge holes was to provide data concerning the provenance, composition and rate of accumulation of this massive feature.

Hole 102 , drilled on the crest of the ridge in a water depth of 3425 meters, ended in a hard siderite-rich zone at a subbottom depth of 661 meters. Nineteen cores of greenish-gray hemipelagic silty clay of late Miocene to Holocene age were recovered. The "perched" lens of sediment on the very top of the ridge, containing abundant well-defined seismic reflecting horizons, is homogeneous Pleistocene silty clay. The bottom of the stratified section lies near the Pliocene/Pleistocene boundary. The clay mineralogy studies (Lancelot et al., this volume) suggest that this Pleistocene lens is derived primarily from glacial debris discharged into deep water off the New England coast, and that the Tertiary sediment below is derived from detritus carried into the ocean by drainage from the Appalachians.

Hole 103 was drilled on the southwestern flank in a water depth of 3964 meters. Total subbottom penetration was 449 meters. Greenish-gray hemipelagic silty clay similar to that obtained at Hole 102 was recovered from the seven cores which range in age from mid-Miocene to early Pliocene. The hole was abandoned after it showed signs of collapse following retrieval of Core 7.

Ten cores containing late early Miocene to middle late Miocene greenish-gray hemipelagic silty clay were recovered at Hole 104 on the northeastern flank of the ridge. This hole was drilled in 3811 meters of water to a subbottom penetration of 617 meters. The hole was terminated to permit the scheduled arrival of the ship in Norfolk.

Sediments from the three sites can be correlated on the basis of a common biostratigraphic zone (planktonic foraminiferal Zone N.17), as well as on compositional similarities. With the help of seismic profiles (Figure 7) we can produce a reasonably good stratigraphic section of the upper part of the ridge (Figure 8). Miocene sediments are generally rich in siliceous microfossils. The sediment of late Miocene to early Pliocene age contains increasing amounts of dolomite, pyrite and glauconite. The uppermost silty Pleistocene deposits are rich in siliceous microfossils and heavy minerals. Sediments recovered from below about 100 meters below bottom were very gassy, containing mostly methane with minor traces of ethane. Hydrogen sulfide was detected in shallow sediment from Hole 104. No Pliocene sediments were recovered at Site 104, where an unconformity separates the hard crusty Pleistocene sediment from middle late Miocene material.

Accumulation rates for the Tertiary deposits are very high, up to $19 \mathrm{~cm} / 1000 \mathrm{yrs}$ for the late middle and early late Miocene of Hole 103 and late Miocene of Hole 104. The Pleistocene accumulation rate calculated for Hole 102 is about $14 \mathrm{~cm} / 1000$ yrs.

The X-ray mineralogy of the fine clays $(<2 \mu)$ in the Neogene sediments of the ridge, and clay samples of the same age from the continental rise farther north (Holes 105 and 106) show striking similarities (Lancelot et al., this volume). The percentage of kaolinite increases gradually with increasing age of sediment, from 5 to 10 per cent in Pleistocene clays to 20 per cent in middle Miocene clays. Samples of the same age are very similar with respect to the amount of mica and chlorite. Pleistocene sediment is rich in mica, chlorite and amphibole, which probably are derived from the mechanical weathering of rock by glacial action (Griffin et al., 1968). The rapid decrease in the constituents relative to kaolinite and montmorillonite toward the Pliocene/Pleistocene boundary substantiates this view. The data show a gradual decrease in relative amounts of chlorite and mica from the Pliocene to the middle Miocene.

Perhaps even more significant is the similarity in composition of clays of similar age in all Neogene sediments collected from Leg 11 drilling sites along the continental margin-from the region of Cat Gap (101), to the Blake-Bahama Outer Ridge $(102,103,104)$, to the continental rise off New York $(105,106)$. The similar composition and regional peculiarities of these sediments suggest that they have a common source. Other studies have shown that abundant chlorite, mica and amphibole have definite northern affinities along the East coast (Hathaway et al., 1970). Thus it is apparent that the Tertiary sediment recovered from as far south as Cat Gap has been transported at least 1000 kilometers from sources to the north. These observations offer strong support to the hypothesis that upper layers of the Blake-Bahama Outer Ridge are composed mainly of fine-grained sediment transported from the north by south-flowing currents. Figure 9, reproduced from Heezen et al. (1966), shows the pattern of flow of the currents as deduced from oriented bottom photographs, piston core samples, characteristics of echograms, and hydrographic data. Bryan's (1970) suggestion that the sediment-carrying bottom currents 


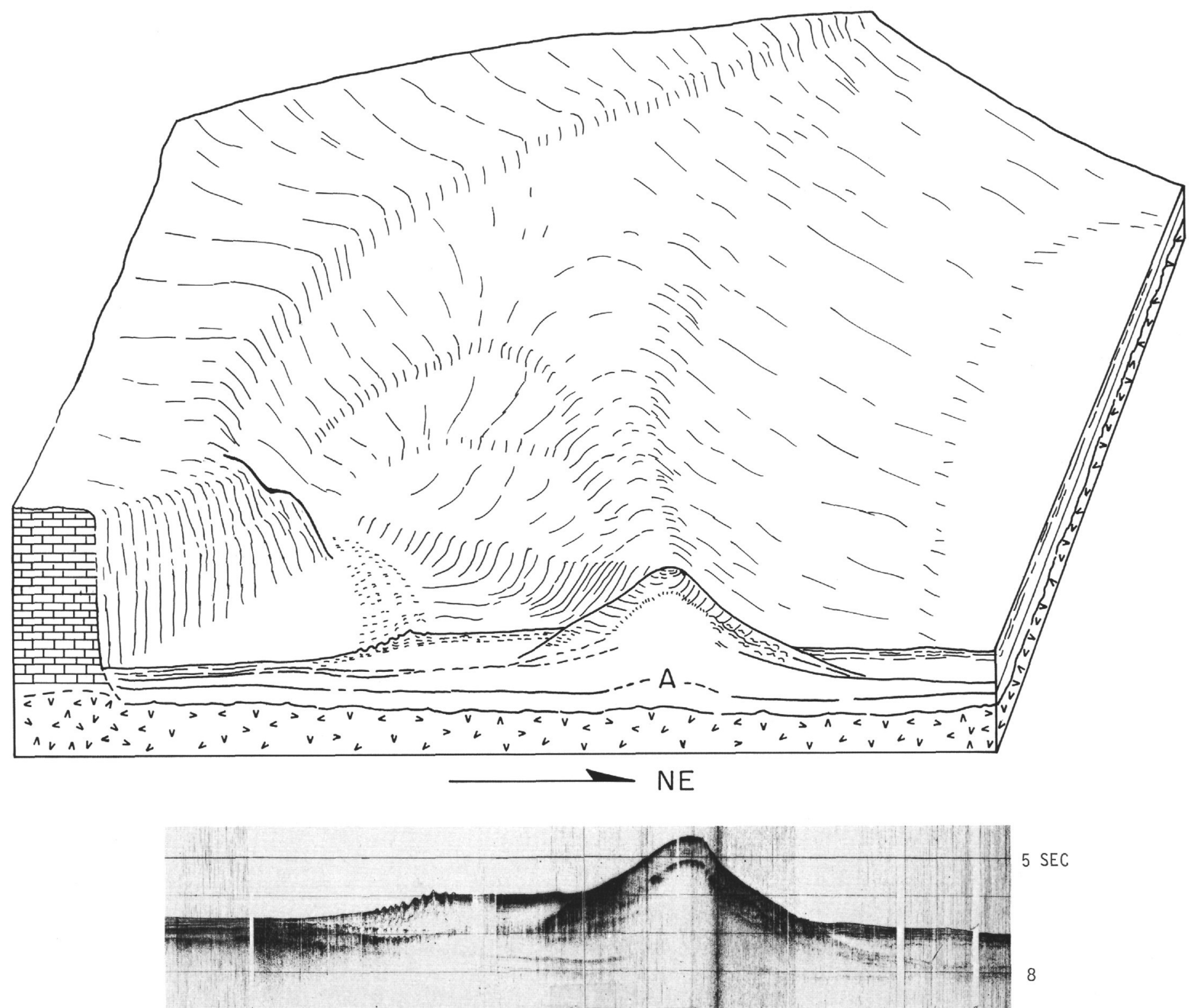

Figure 7. Sketch of the physiography and seismic data of the Blake-Bahama Outer Ridge. The seismic profiler record below the sketch crosses the ridge very near Sites 102, 103 and 104. See Figure 8 for detail. 


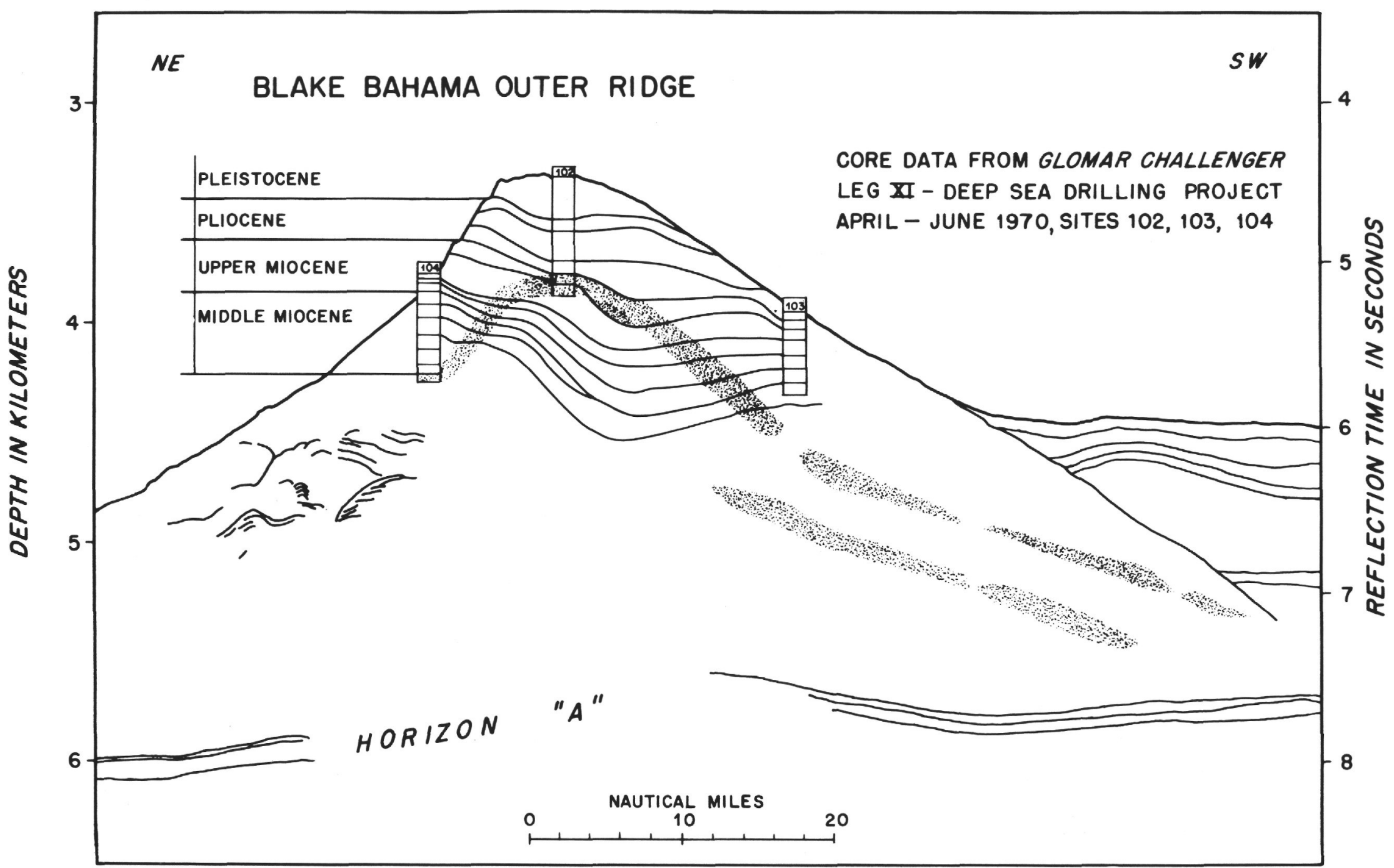

Figure 8. Tracing of the seismic profiler record across the Blake ridge with drill sites indicated. Bedding planes in the crestal region are drawn on the basis of biostratigraphic correlations in the three holes and on behavior of seismic reflectors. Stippling indicates a conformable reflector in the crestal region and diffuse reflectors on the southwest flank. Bedding is disturbed on the northeast flank. See Site Reports for a reproduction of the seismic record. 


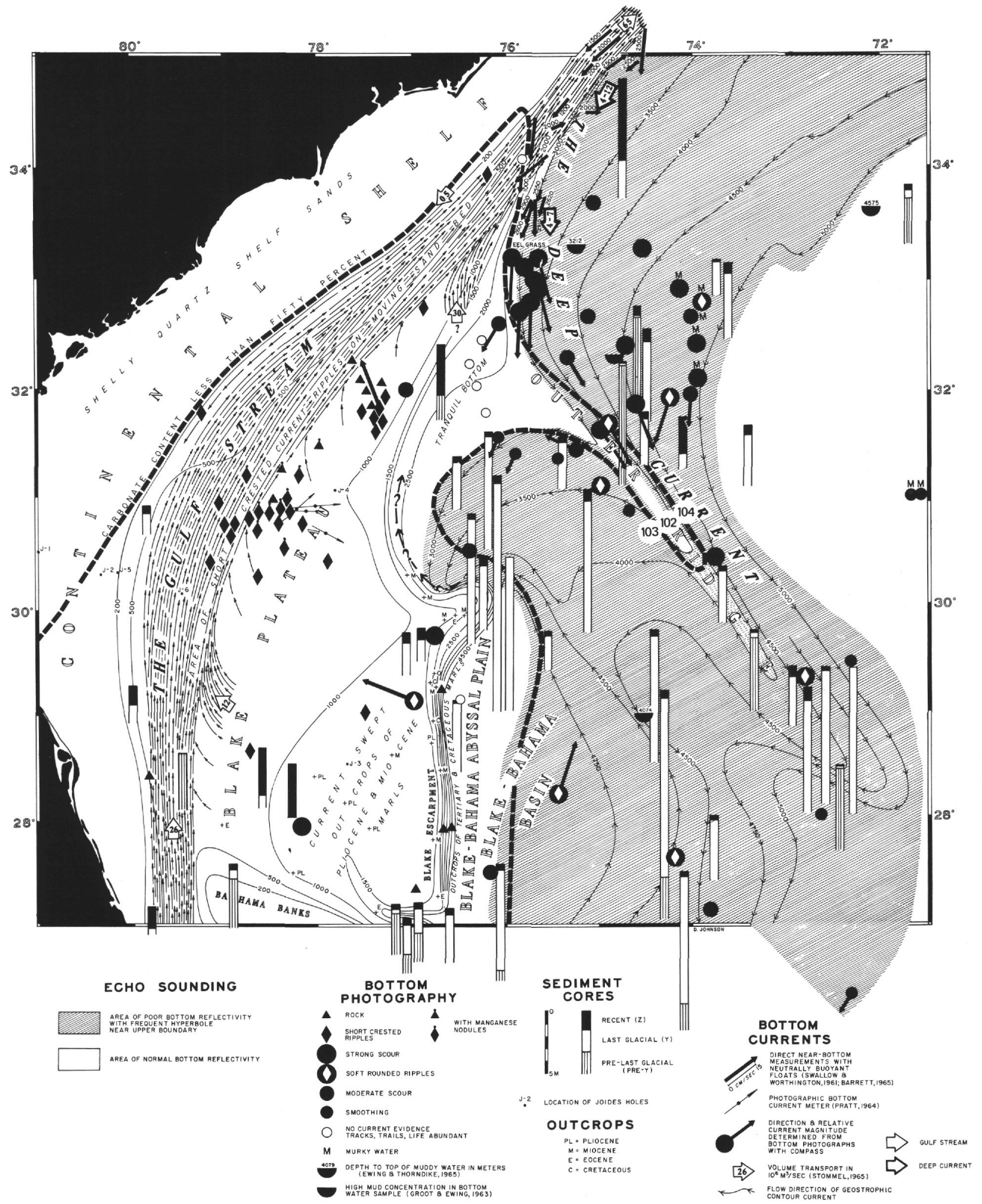

Figure 9. Diagram indicating bottom currents and sediments on the Blake Plateau and Blake-Bahama Outer Ridge (from Heezen et al, 1966). The diagram is based on the study of piston core samples, echograms and bottom photography. 
were deflected seaward at the juncture of the deeper part of the Gulf Stream and the Western Boundary Undercurrent appears to explain the location of the Outer Ridge, but sampling of the deeper layers, to determine whether they contain an appreciable amount of southern (carbonate) sediments, will be necessary to test whether turbid water coming off the Blake Plateau may have contributed sediment to the early development of the ridge.

A hypothetical explanation of the development of the Ridge is shown by the diagrams of Figure 10. In these sketches, we ignore the prominent reflector that is conformable to the sea floor at about 0.6 second reflection time. This reflector is probably the result of diagenesis and has no direct application to the building of the ridge.

Although we believe that sediment-laden currents have been the principal agents in the construction, we do not rule out the possibility that slumps have modified the basic structure, particularly in the region between the drilling sites and the head of the ridge. We cannot even be certain that the prominent scarp-like east-west feature where Hole 103 was drilled is not the toe of a large slump, but there appears to be a reasonable way of explaining it as a depositional feature, as indicated in Figure 10.

Our model assumes a level sea floor at Horizon A time, that is, middle Eocene. At about that time the North Atlantic was open to sources of relatively cold Arctic water, thus initiating strong circulation of the deep water along the margin of the basin. This boundary undercurrent apparently prevented significant deposition along the margin and may have caused erosion during the early stages, but at some time between middle Eocene and Miocene the Outer Ridge began to develop. By middle Miocene time sediment accumulation was very fast, almost $20 \mathrm{~cm} / 1000$ yrs. If this rate can also be applied to the older strata, we can deduce that significant accumulation of the ridge sediments began during the late Oligocene. Whether the onset of ridge building was the result of an increase in sediment supply or of a change of bottom environment is not known. One can imagine an early current regime similar to the one that built the Outer Ridge, but lacking a supply of sediment. Alternatively, there may have been a sediment-laden undercurrent but one that flowed too rapidly to permit deposition. In the first case, ridge construction may have begun when a sediment source was tapped. The shape and location of the ridge might then be determined by a structural feature, not yet discovered, that diverted the flow away from the continental margin. Alternatively, ridge building may have commenced when turbid water started flowing off the northern part of the Blake Plateau and interacted with the undercurrent in the manner suggested by Bryan (1970). We illustrate this latter alternative in Figure 10a because: 1) we have not observed a structural protuberance that might have deflected the undercurrent and, 2) the small amount of accumulation of sediments on the plateau during most of the Tertiary (JOIDES, 1965) and the evidence of extensive erosion (Ewing et al., 1966) are consistent with the hypothesis that a significant amount of sediments has been swept off the plateau and deposited in the vicinity of the Outer Ridge. The earliest of the eroded sediments may constitute part of the Outer Ridge illustrated in Figure 10a, which became the nucleus of the present Blake Ridge.

In the next stage of construction we assume that the boundary under-current was the dominant, if not the sole, influence. Apparently during the early Miocene some of the undercurrent began to cut across the Outer Ridge at about latitude $30^{\circ} 45^{\prime} \mathrm{N}$, and started to develop a spit toward the west (Figure 10b). The deeper part of the undercurrent probably flowed around the southeastern end of the ridge and back toward the northwest as it appears to do now (Figure 9; Heezen et al., 1966; Amos et al., 1971). As this westward-trending spit and the Outer Ridge grew upward, possibly in response to an increase in the thickness and/or competence of the sediment-laden current, their crests migrated toward each other. At the same time their lower flanks may have undergone soft sediment deformation, thus producing the distortion of reflectors seen along the northeastern flank of the main ridge.

Figure 10c shows the present structure created by a general continuation of current-controlled deposition through the Pliocene and Pleistocene, possibly with some changes in sediment supply or current velocity. This later deposition, particularly that during the Pleistocene, has completely filled in the region between the crests of the main ridge and the spit at the location of Hole 102.

During the Holocene the currents diminished and a sediment blanket, thickest on the west, was deposited.

We return now to consider the reflector that lies about 0.6 second reflection time below the sea floor and is conformable to it (Figures 7 and 8). This reflector was called Reflector Y by Markl et al. (1970) who noted that it cut minor reflectors that appeared to be associated with bedding planes and, therefore, was probably due to diagenesis. The drilling results offer some clues as to the nature of the diagenesis.

Almost every core brought up from the three holes drilled on the Outer Ridge contained gas, primarily methane with a minor trace of ethane. Unfortunately, no effort was made to measure the volume of gas or to make estimates of the relative amounts from cores 

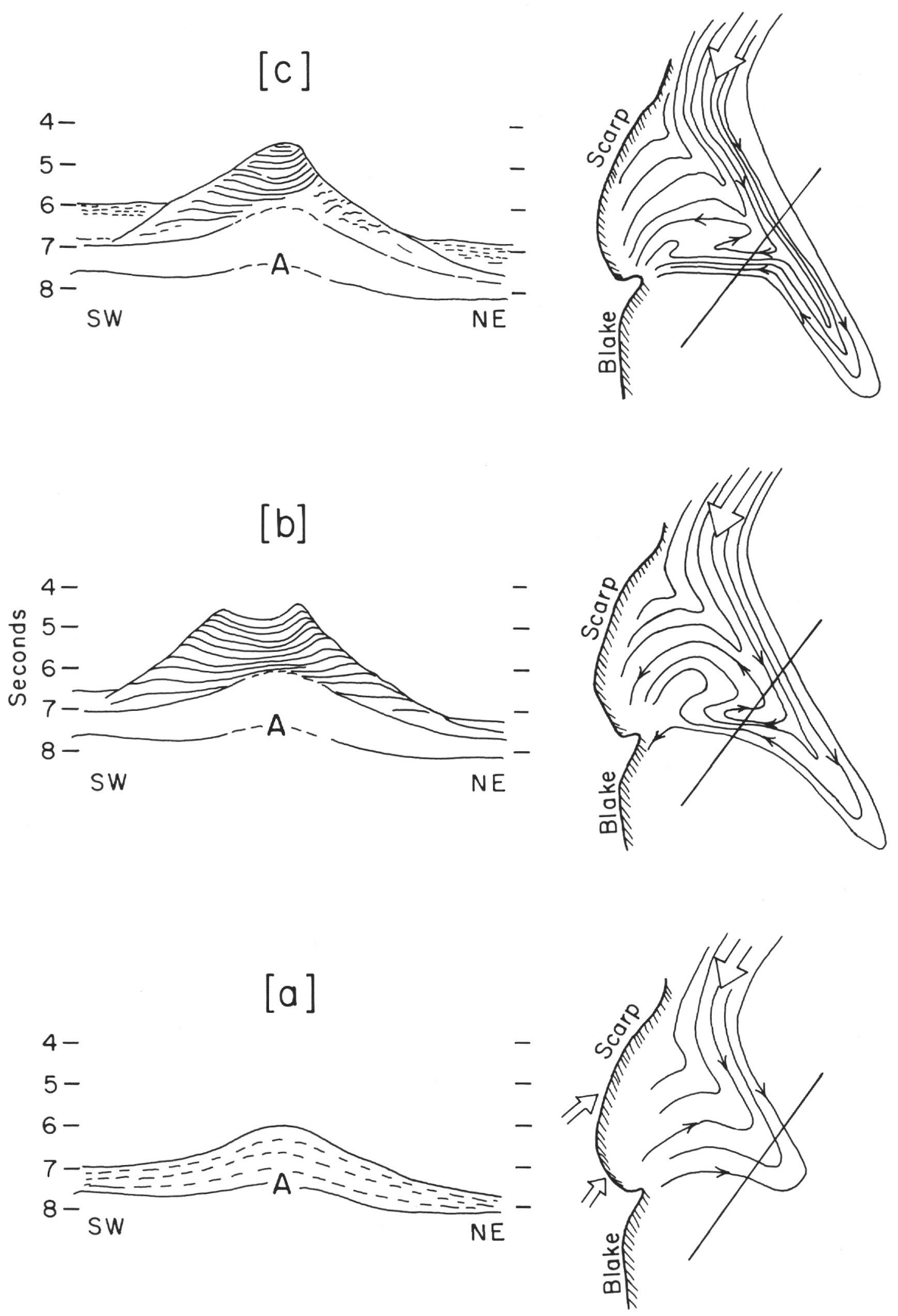

Figure 10. Hypothetical development of the Blake ridge on a formerly level sea floor of Horizon $A$ time. Initial building was due to the interaction of turbid water flowing off the Blake Plateau with the western boundary undercurrent. Later development was influenced primarily by erosion and deposition controlled by the contour-following undercurrent. 
taken at different depths; but from a few meters below bottom to the total depth penetrated, there was enough gas present to cause as much as 50 per cent extrusion of the samples from the core barrel.

Drilling of Hole 103 had to be terminated prematurely because of technical problems, and there had been no significant drilling break. There were noticeable drilling breaks near the bottoms of Holes 102 and 104, which initially were judged to correspond to the conformable reflector. An increase in the amount of nodular siderite was found near the anticipated depth of the reflector in Hole 102, and a hard layer or large nodule of ankerite was cored just before Hole 104 was abandoned (also near the depth of the reflector).

Correlation of these sedimentological and drilling breaks with the conformable reflector led to a calculated interval velocity of about $2 \mathrm{~km} / \mathrm{sec}$ for the overlying gassy sediment, a value surprisingly high for hemipelagic mud. These observations led to deductions by Stoll et al. (1971) that these sediments might contain hydrated methane and that this could have the effect of increasing the sound velocity. A substantial amount of research on the hydrates of natural gases has been summarized by Katz et al. (1959) and indicates that temperature and pressure in the sediments on the Blake Ridge are well within the hydrate region of the P-T diagram for methane. Experiments by Stoll et al. showed that under conditions of pressure and temperature appropriate to the drilling site, the introduction of methane into saturated sand apparently did result in the formation of hydrate and caused an increase in sound velocity in the specimen from about $1.7 \mathrm{~km} / \mathrm{sec}$ initially to $2.5 \mathrm{~cm} / \mathrm{sec}$ after several hours of gassing.

There is some doubt that the correlations between lithology, drilling rate, and seismic reflector that were initially made for Holes 102 and 104 are correct, but it appears that they did lead to the most probable explanation of the conformable reflector $\mathrm{Y}$. The tendency of the reflector to remain so closely parallel to the sea floor suggests that its position is more dependent on temperature than on pressure. Because of the low density of unconsolidated sediment, an isobar should be more horizontal than the sea-floor contour; but an isotherm would probably be nearly parallel to the sea floor. An average value of the temperature gradient in deep-sea sediment for the upper few tens of meters depth is $0.07^{\circ} \mathrm{C} / \mathrm{m}$ (Langseth and von Herzen, 1970). The measured heat flow values for the Blake Ridge are low, 1.0 H.F.U. When we consider that water content of the sediment below about 200 meters is relatively low (Paulus, this volume) and that conductivity varies inversely as water content (Bullard, 1963), we can estimate that the average thermal gradient in the upper 500 meters of the Outer Ridge can be as low as $0.04^{\circ} \mathrm{C} / \mathrm{m}$. Rough calculations based on this figure indicate that 500 meters, the approximate depth below bottom of reflector $Y$, is the order of magnitude depth that methane hydrate could exist in the Blake Ridge. Below that depth the temperature would be too high, and undissolved methane would be gaseous.

This suggests at least two hypotheses to account for reflector $Y$ : (1) the reflector may correspond to the isotherm that separates a gas environment from a hydrate environment, and (2) the hydrate/gas isotherm may be below reflector $Y$, and the reflector is due to a concentration of hydrated methane produced by gas migrating upward from the deeper layers into the hydrate-sustaining environment. In the first hypothesis it must be assumed that there is a sufficient quantity of methane above and below the reflector to exceed the partial pressure necessary to account for the presence of undissolved gas. Under these conditions, the excess methane above the critical isotherm would produce hydrate; below the isotherm it would be in the form of undissolved gas. Depending on the amounts of gas and hydrate involved, it is not unreasonable that significant acoustical impedance contrast would exist at the critical isotherm. The second hypothesis is based on the assumption that gas is migrating upward in the ridge sediments and that this has produced a concentration of hydrate just above the critical isotherm. This hypothesis does not require that sediments above the reflector contain other than dissolved methane but it does require some supersaturation below the reflector.

Possible evidence for vertical migration of gas was noted in some of the deeper cores from Hole 106. These cores had distinct vertical fractures along which there was a significant concentration of siderite (Lancelot et al., this volume).

\section{BASIN, RISE, AND SLOPE SOUTHEAST OF NEW YORK}

Numerous seismic profiler traverses in this region had given the general picture of the seismic stratigraphy before the drilling was accomplished (Ballard, 1966; Ewing et al., 1967; Emery et al., 1970). As in many other parts of the Atlantic, Horizon A appears to correspond to a major change in depositional regime. Pre-Horizon A deposition had the principal effect of smoothing pre-existing topography and thus creating a remarkably level sea floor. Post-Horizon A deposition, on the other hand, resulted in the building of major sedimentary features, the most prominent in the western Atlantic being the continental rise and the Blake-Bahama Ridge system. Some later leveling was accomplished during the Pleistocene by turbidity current deposition, but the smooth areas created during this time are at least an order of magnitude smaller in extent than the plains of Horizon A time. Emery et al. (1970) have suggested that prior to 
Horizon A time the main basin did not receive detritus from the continent because of an intervening basement ridge located near the continental slope. They propose that construction of the rise began approximately in Middle Eocene time when detrital sediments buried and overflowed the Outer Ridge. We have suggested that the transition from basin leveling to continental rise construction was mainly due to the onset of the vigorous bottom water movement, judged to correspond to the time when the opening of the Atlantic had proceeded far enough to permit large-scale inter-basin circulation of deep water (Ewing and Ewing, 1970; Berggren and Hollister, 1972).

The four holes drilled during Leg 11 and one hole drilled during Leg 2 in this region are shown, in relation to the physiography and seismic stratigraphy, in the block diagram of Figure 11. A seismic profiler section through Holes 105 and 106 is shown in Figure 12. Horizon $\mathbf{A}$ is a prominent reflector in the deeper areas. A reflector slightly below Horizon A, labeled A* in Figure 12, is observed over a substantial portion of this region but is not as prominent and cannot be traced as far as Horizon A.

\section{Basalt (Basement)}

Basalt was encountered in Hole 105 at 620 meters below bottom and correlates well with the rough acoustic basement observed in the profiler records. The sediment-basalt contact is sharp, and although the basal sediment has been somewhat metamorphosed, it is tentatively judged to be the result of hydrothermal alteration rather than to baking by a sill intrusion (Bryan, this volume). A thin layer of graded pyroclastics is present in the zone of altered sediment a few centimeters above the basalt. The hole was drilled about 10 meters into the basalt, which contains a few small sediment inclusions.

As indicated in Figures 11 and 12 the basement is rough in the vicinity of Holes 105 and 8 , but apparently is much smoother to the west. Near Hole 106 , and landward, it appears to be about as smooth as it is in the Cat Gap area.

\section{Late Jurassic and Neocomian Limestones (Horizon $\beta$-Basement)}

The layer overlying the basalt is only moderately reflective, but it is easily enough observed in profiler records so that there is no doubt about its general characteristics. Its average regional thickness corresponds to 0.3 to 0.4 seconds reflection time, and its mode of deposition was such that it tended to fill basement depressions and form a level sea floor. The presence of flow structures and clasts in the cores obtained from this layer in Hole 105 is interpreted as evidence that local transport by gravity and weak currents from topographic highs into neighboring lows was an important part of the leveling process (Y. Lancelot et al., and D. Bernouilli, this volume). The top of this layer is designated $\beta$ in Figures 11 and 12 . The $\beta$-Basement section is the seismic and, to a large extent, the stratigraphic equivalent of the $\beta$-B layer in the Cat Gap area, consisting of alternating layers of clays and limestones of Neocomian and Late Jurassic ages. The basal unit of the layer is a red claystone of Kimmeridgian/Oxfordian age that grades upward into a red clayey limestone. A thin veinlet of native copper was found 18 meters above the basalt contact. In the Cat Gap area, similar red limestones are underlain by grayish-white to white limestone of Tithonian, Valanginian, and Hauterivian ages, the upper part of which correlates with Horizon $\beta$. Hole 105 was drilled on a regional basement high, and Horizon $\beta$ is not clearly recorded at the drilling site in the record reproduced in Figure 12. However, the numerous profiler records in the area show that $\beta$ is of regional extent and is almost certainly present at Site 105, although the $\beta$-Basement interval is thinner than the regional average. The top part of the limestone sequence did not correspond to a sharp change in drilling rate as it did, for example, at Hole 101; so it is not too surprising that it does not produce a sharp reflection on the profiler records.

\section{Barremian-Cenomanian Black Clay (Horizon $A^{*}$-Horizon $\beta$ )}

The section between Horizon $\beta$ and Horizon $A^{*}$ (Figure 12) was well sampled at Hole 105 and consists of very dark, sometimes coal-black, clay containing a large percentage of organic matter. Although somewhat darker in color, it is certainly the same lithologic unit as the Horizon A-Horizon $\beta$ section that was cored at Hole 101. It has a firm, plastic consistency and appears as a homogeneous (transparent) layer in the profiler records. Although the deposition of the underlying calcareous sediments had already accomplished an appreciable filling of the basement depressions, the dark clay deposition produced some additional leveling.

\section{Volcanic-Rich Section (Horizon A-Horizon A*)}

This section was well sampled at Hole 105, was apparently sampled in Hole 7 (Ewing et al., 1969) and may have been sampled in Hole 8 (Peterson et al., 1970). In Hole 105 it consists of varicolored, volcanogenic clays and is entirely devoid of fossils. It is substantially enriched in zinc, manganese and iron. The two deepest cores (below the Eocene chert) in Hole 7 recovered similar sediment; a smear of similar material was found in the bit after the drilling of Hole 8 was terminated, also apparently below the Eocene chert. It is not possible to determine how much of the time interval between Cenomanian and Eocene is represented by this section and how much may be accounted for by hiatuses. The section can be traced 


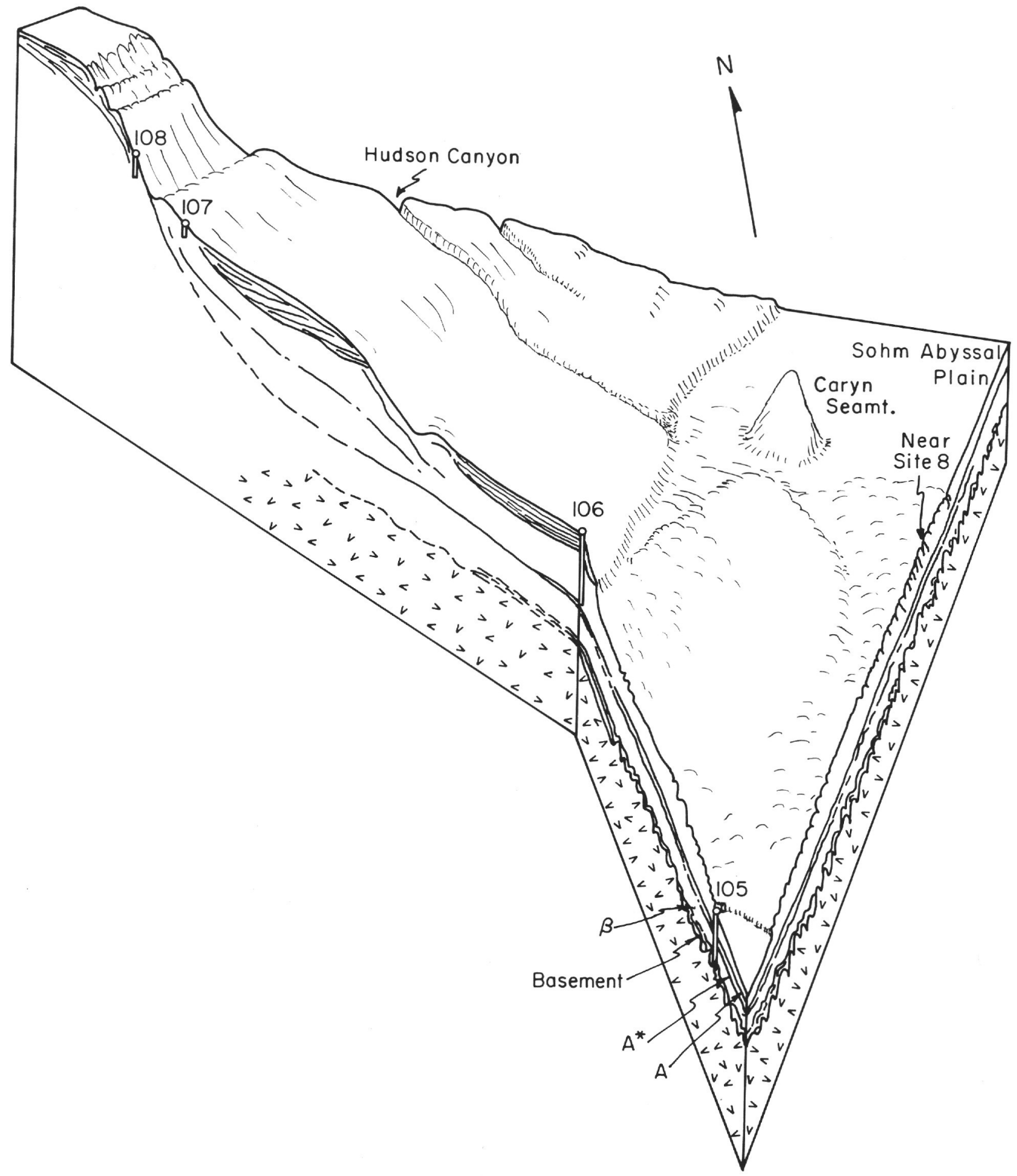

Figure 11. Sketch of the physiography, seismic and drilling data on the continental rise and slope southeast of New York. Hole depths at Sites 105, 106, 107 and 108 are 633, 1015, 78 and 209 meters, respectively. See Figure 12 for a more detailed illustration of the seismic data between Holes 105 and 106. Principal units are: basalt (checked); Neocomian and Late Jurassic limestones and chalks ( $\beta$-basement); Early Cretaceous dark clay ( $A$ *- $\beta$ ); multi colored volcanogenic clays of uncertain age $\left(A-A^{*}\right)$; Eocene-Pliocene hemipelagic mud (unstratified layer above Horizon A); and, Quaternary turbidites (upper stratified layer at Site 106). The latter layer is present also in depressions between the lower continental rise hills and in the abyssal plains (Figure 12) but difficult to show in the sketch. 


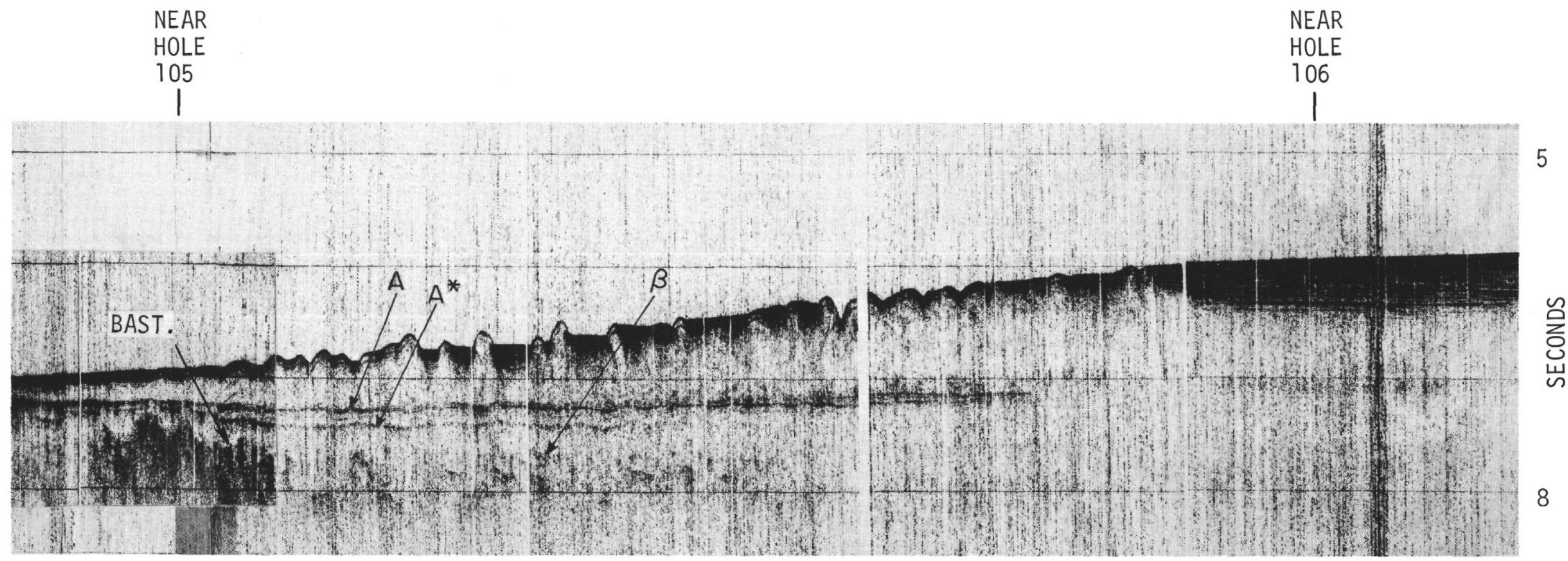

Figure 12. Vema-23 seismic record section between Holes 105 and 106 . Vertical exaggeration is $25 \times$. Note the unfilled depression approximately half way between Sites 105 and 106, possibly a channel through which turbidites flow to the Hatteras plain after overflowing the large pond at Site 106. 
seismically over a substantial portion of the western North American Basin (Ewing et al., 1970). It may be as thick as 300 meters in a broad region southwest of Bermuda, as at Site 5, for example, but is usually thinner. At Site 105 it is only 50 meters thick, but it thickens toward Sites 8 and 106. For a more detailed mineralogical and sedimentological description of this layer, see Lancelot et al. (this volume).

\section{Horizon A and Post-Horizon A Sediments}

Before discussing the sediments above Horizon A, it seems worthwhile to review the evidence about the age and possible depositional synchronism of the horizon in this area. The age of the silicified zone that apparently corresponds to Horizon A in Holes 6 and 7 was determined from foraminifera as early middle Eocene (Berggren, 1969 in Ewing et al., 1969), and in Hole 8 it was determined from radiolarians as early middle or latest early Eocene (Cita et al., 1970 in Peterson et al., 1970). Hole 106 was terminated in a silicified zone at the approximate level of Horizon A, and the deepest sample contains some poorly preserved Eocene radiolarians (W. R. Riedel, personal communication). The drilling rate graph at Hole 105 suggests that near Horizon A a thin hard layer, possibly chert, was penetrated a few meters above the first core from the volcanogenic layer. The interval was not sampled but a tentative correlation of these drilling data with the presence of Eocene silicified beds seems reasonable. Thus, although no evidence definitely proves the Horizon A to be an early to middle Eocene time marker, the data obtained from these holes are compatible with this concept.

There is some uncertainty in tracing Horizon A westward, but it appears to continue as shown in Figure 11, possibly cropping out on the continental slope at Site 108 , but probably corresponding to a reflector at about 0.3 seconds below bottom. Only two cores were recovered at Site 108, one of late middle Eocene age at 57 meters and the other of early middle Eocene age at 75 meters below sea floor. Both cores contain abundant siliceous microfossils, but neither contains chert nor was there evidence for silica cementation. Gibson and Towe (1971) also report earliest Middle Eocene or late early Eocene siliceous sediment recovered by dredging the Hudson and other canyons; and their samples, which are the same age as the cherts at Site 8 , are not cherty or cemented. Therefore, if Horizon A is a continuation of the chert zone from the basin to the slope, it must be somewhat time-transgressive and correspond to the reflector at 0.3 seconds below bottom (not reached) at Site 108. A second possibility is that Horizon A does not continue to the slope and does not join any of the reflectors there. Still a third possibility is that Horizon A should not be correlated with the chert zone but with the early Tertiary hiatus beneath the cherts. The latter alternative is consistent with the data from Holes 101 and 105 where only minor amounts of chert, if any, were penetrated, yet Horizon $\mathbf{A}$ is a prominent reflector in the seismic records.

Whether we correlate Horizon A with the chert beds or with a hiatus slightly below them, there is very little doubt that the sea floor in this region during middle Eocene time was an extensive plain and that almost all of the continental rise sediments were deposited later. In fact, the recovery of Middle Miocene cores within 50 meters of Horizon A at Sites 105 and 106 indicates that most of the lower continental rise was built after Early Miocene time. With only 50 meters of section to represent the Early Miocene, Oligocene, and probably much of the Eocene, we can deduce that accumulation during most of this period was much slower than it was afterwards or that erosion removed a substantial amount of the section. Whether these same units are thin or missing under the upper continental rise cannot be determined from the available data. The seismic section (Figure 12) shows that at least one additional layer onlaps Horizon A westward of Hole 105, and this could indicate a substantial thickening of the late Eocene-early Miocene beds toward the slope.

The Miocene and Pliocene deposits on the lower rise are hemipelagic muds and correspond to the unstratified part of the section above Horizon A at Sites 105 and 106. The highly stratified uppermost sediments at Site 106 are Quaternary turbidites ponded in an elongate depression in the hemipelagic mud layer that makes up the lower continental rise hills. Whether this depression and the associated hills were created by a process involving mass transport of material toward the basin as suggested by Ballard (1966) and Emery et al. (1970) or by depositional processes associated with contour currents has not been definitely answered by the drilling. The similarity of these hemipelagic muds with those of the Blake Ridge suggest both a common source and similar depositional process. We are inclined to the view that the ridge of lower continental rise hills that forms the outer bank of the depression was produced primarily by current-controlled deposition rather than by tectonics, but both processes may have been important. Large-scale slumping definitely seems to have been involved in exposing the Eocene beds on the continental slope. Regardless of the origin of this depression, it clearly provided a catchment basin for the Pleistocene turbidites which filled it and have apparently overflowed through the Hatteras transverse canyon and, to a lesser degree, through gaps in the lower continental rise hills near the Hudson Canyon.

\section{SUMMARY OF PRINCIPAL RESULTS}

1. The basal deposits at Site 100, clayey limestones of Oxfordian-Callovian (?) age, are the oldest deep sea sediments yet obtained. Their age (155 to 160 million 
years), along with indications that their depositional environment was appreciably shallower than the present, are consistent with an early Jurassic opening of the Atlantic Ocean. The basal sediments at Site 105, which is farther from the margin than Site 100, are 150 to 155 million years old and are consistent with a similar age for the opening. Site 105 is near the eastern boundary of the magnetically "quiet" zone. Thus, if the quiet zone corresponds to crust generated during a period when there were no magnetic field reversals, that period ended about 155 to 160 million years ago. Site 100 is in a region where the boundary of the magnetically quiet zone is not as well defined, but this site apparently also lies within the quiet zone.

2. The data from Hole 105 and Hole 10 indicate a rate of $3.5 \mathrm{~cm} / \mathrm{yr}$ for the opening of this part of the Atlantic between 155 and 80 million years b.p. If the extrapolated age of 120 million years suggested by Peterson et al. (1970) is used for the age at Hole 9, a rate of $4.4 \mathrm{~cm} / \mathrm{yr}$ is indicated for the period 155 to 120 million years b.p. From these data the age of initial rifting of the Atlantic can be calculated to be about 180 to 200 million years before present.

3. The cores from Sites 99, 100, 101 and 105 have provided exceptionally well-preserved calcareous microfossils for biostratigraphic studies of the Neocomian and late Jurassic. Bernoulli (this volume) has pointed to many similarities between units of the western North Atlantic deposits and those of the Tethyan Mesozoic.

4. The limestones and chalks constituting the Horizon $\beta$-Basement section indicate that the basin floor was subsiding but remained above the depth of calcium carbonate compensation until Hauterivian/ Barremian time.

5. The Barremian-Cenomanian dark clay section, which constitutes most of the material between Horizons $\mathrm{A}$ and $\beta$, was deposited below the calcium carbonate compensation depth under stagnant conditions. Similar sediments, also rich in carbonaceous material, have been reported in the eastern basin of the Atlantic (Hayes et al, 1971).

6. At Site 105 between the depths of 240 and 290 meters below the sea floor (Horizon A-Horizon $\mathrm{A}^{*}$ ), there is a layer of unfossiliferous, metal-enriched volcanogenic clay that is similar in several respects to the Red Sea deposits described by Bischoff (1969). This similarity suggests (Lancelot et al., this volume) that volcanic activity was intense and the depositional environment was quiet, permitting precipitation of the metals from the sea water. The lack of fossils unfortunately prohibits dating of these deposits, other than Late Cretaceous-Early Tertiary. Seismic data indicate that the layer is widespread in the western basin, and samples of similar sediment apparently were recovered below the Horizon A cherts at Hole 7, Leg 1 and Hole 8, Leg 2.

7. The absence of appreciable accumulations of Late Cretaceous deposits at the Leg 11 sites suggests that most of the sediment of this age was swept away from the marginal region and deposited farther out in the basin. This process probably continued into the Early Tertiary as evidenced by the presence of Late Cretaceous fossils in the Eocene turbidites recovered at Site 6 (Ewing et al., 1969). In addition, some scouring by deep boundary currents may have commenced during this time.

8. Of the deep sea holes drilled to date which penetrated into the Cretaceous and produced a reasonable number of datable samples, most have shown an anomalously thin section of Early Tertiary (pre-Horizon A) sediment, e.g., Holes 9, 13, 99, 101, $105,135,136,138$ and 140 in the Atlantic (Legs 2, 3, 11 and 14); Holes 51, 59, 61, 66, and 164 through 171 in the Pacific (Legs 6,7 and 17). The chert beds that have been associated with seismic Horizon A typically lie within or just above this shortened section (or hiatus) and there is a serious question as to whether the reflection is caused by the cherts or by an impedance contrast across the hiatus.

9. By Middle Eocene time the western part of the basin had become well leveled, at least partly by turbidity currents which caused erosion of the marginal regions and ponding in the deeper parts. The opening of the northernmost North Atlantic to sources of cooler Arctic water soon afterwards permitted the initiation of major circulation in the deep water which significantly affected later deposition in the basin. The deep boundary currents apparently created a nondepositional, or even erosional, environment which resulted in very little accumulation of Middle and Late Eocene, Oligocene, and Early Miocene sediment along the western margin of the basin while permitting deposition in other parts of the basin. During the Early-Middle Miocene a major influx of hemipelagic mud began along the margin. This sediment, most of which apparently came from the north, was carried by the southwest-flowing deep boundary current, and its deposition has been the principal agent in constructing the continental rise and the Blake-Bahama Ridge system. This regime of sedimentation appears to have persisted up to the present, although probably with significant variations in current strength and sediment supply.

10. A broad terrace-like portion of the continental rise between the Hudson and Hatteras canyons was penetrated at Site 106 and was found to result from ponding of Pleistocene turbidites in a depression 
behind the lower continental rise hills. Except where such traps were present, the Quaternary turbidites largely bypassed the continental rise and were deposited in the modern abyssal plains.

11. The data from Hole 98 in Northeast Providence Channel, together with the Bahama wells, have shown conclusively that the Bahama channels were formed as the platform subsided, giving rise to rapid upward growth of reefs along the walls, with relatively slow deposition in the channels. During their development, the channels have probably been the principal passageways of the nutrients to the back reef regions of the banks.

12. The recovery of gassy (primarily methane) sediments on the Blake Ridge, which appeared to have an anomalously high in-situ sound velocity, led to an investigation that has shown that gas hydrates (clathrates) are likely to be present in some marine sediments in sufficient amounts so as to cause significant effects on sound velocity, acoustic impedance, engineering properties (Stoll et al., 1971), and sediment diagenesis.

\section{REFERENCES}

Amos, A. F., Gordon, A. L. and Schneider, E. D., 1971. Water masses and circulation patterns in the region of the Blake-Bahama Outer Ridge. Deep-Sea Res. 18, 145 .

Andrews, J. E., 1967. Blake outer ridge: Development by gravity tectonics. Science. 156, 642 .

Bader, R. G., Gerard, R. D., Benson, W. E., Bolli, H. M., Hay, W. F., Rothwell, W. T., Jr., Ruef, M. H., Riedel, W. R. and Sayles, F. L., 1970. Initial Reports of the Deep Sea Drilling Project, Volume $I V$. Washington (U.S. Government Printing Office), $753 \mathrm{pp}$.

Ballard, J. A., 1966. Structure of the lower continental rise hills of the western North Atlantic. Geophysics. 31,506 .

Berggren, W. A., 1969. Cenozoic foraminiferal faunas. In Ewing et al., 1969. Initial Reports of the Deep Sea Drilling Project, Volume I. Washington (U.S. Government Printing Office), 594.

Berggren, W. A. and Hollister, C. D., 1972. Paleogeography, paleobiogeography and the history of circulation of the Atlantic Ocean. Soc. Econ. Pal. Min. Spec. Pub. (in press).

Bischoff, J. L., 1969. Red Sea geothermal brine deposits: Their mineralogy chemistry and genesis. In Hot Brines and Recent Heavy Metal Deposits in the Red Sea. E. T. Degans and D. A. Ross (Eds.), New York (Springer-Verlag), $368 \mathrm{pp}$.

Bryan, G. M., 1970. Hydrodynamic model of the Blake Outer Ridge. J. Geophys. Res. 75(24), 4530.

Bullard, E. C., 1963. The flow of heat through the floor of the ocean. In The Sea. M. N. Hill (Ed.). New York (Wiley), 3, 218.
Cita, M. B., Nigrini, C. and Gartner, S., 1970. Biostratigraphy. In Peterson, M. N. A., et al., 1970. Initial Reports of the Deep Sea Drilling Project, Volume II. Washington (U.S. Government Printing Office), 391.

Emery, K. O., Uchupi, E., Phillips, J. D., Bowin, C. O., Bunce, E. T. and Knott, S. T., 1970. Continental rise off eastern North America. Bull. Am. Assoc. Petrol. Geologists. 54, 44.

Ewing, J., Anderson, R. and Ewing, M., 1967. Seismic reflection profiles across the lower continental rise between the Hudson and Hatteras canyons (abstract). Trans. Am. Geophys. Union. 48(1), 127.

Ewing, J. and Ewing, M., 1964. Distribution of oceanic sediments. In Studies in Oceanography. Tokyo (Geophys. Inst. Univ. Tokyo), 525.

Ewing, J. and Ewing, M., 1970. Seismic reflection. In The Sea. A. E. Maxwell (Ed.). New York (Wiley), 4,1 .

Ewing, J., Ewing, M. and Leyden, R., 1966. Seismic profiler survey of the Blake Plateau. Bull. Am. Assoc. Petrol. Geologists. 50(9), 1948.

Ewing, J., Windisch, C. and Ewing, M., 1970. Correlation of Horizon A with JOIDES bore-hole results. J. Geophys. Res. 75(29), 5645.

Ewing, J., Worzel, J. L., Ewing, M. and Windisch, C., 1966. Ages of Horizon A and the oldest Atlantic sediments. Science. 154 (3753), 1125.

Ewing, M. and Thorndike, E. M., 1965. Suspended matter in deep ocean water. Science. 147(3663), 1291.

Ewing, M., Worzel, J. L., Beall, A. O., Berggren, W. A., Bukry, D., Burk, C. A., Fischer, A. G. and Pessagno, E. A., Jr., 1969. Initial Reports of the Deep Sea Drilling Project, Volume I. Washington (U. S. Government Printing Office), $672 \mathrm{pp}$.

Gibson, T. G. and Towe, K. M., 1971. Eocene volcanism and the origin of Horizon A. Science. 172(3979), 152.

Griffin, J. J., Windom, H. and Goldberg, E. D., 1968. The distribution of clay minerals in the world ocean. Deep-Sea Res. 15, 433.

Habib, D., 1970. Middle Cretaceous palynomorph assemblages from clays near the Horizon Beta deep-sea outcrop. Micropaleontology. 16(3), 345.

Hathaway, J. C., McFarlin, P. F. and Ross, D. A., 1970. Mineralogy and origin of sediments from drill holes on the continental margin of Florida. U.S. Geol. Survey, Profess. Paper 581E. 26 pp.

Hayes, D. E., Pimm, A. C., Benson, W. E., Berger, W. H., von Rad, U., Supko, P. R., Beckmann, J. P., Roth, P. H. and Musich, L. F., 1971. Deep Sea Drilling Project: Leg 14. Geotimes. 16(2), 14.

Heezen, B. C. and Hollister, C. D., 1964. Deep-sea current evidence from abyssal sediments. Marine Geol. 1, 141. 
Heezen, B. C., Hollister, C. D. and Ruddiman, W. F., 1966. Shaping of the continental rise by deep geostrophic contour currents. Science. 152(3721), 502.

Heezen, B. C. and Tharp, M., 1968. Physiographic diagram of the North Atlantic, (2nd Edition). Geol. Soc. Am.

JOIDES, 1965. Ocean drilling on the continental margin. Science. 150 (3967), 709.

Katz, D. L., Connell, D., Kobayshi, R., Poettmann, F. H., Vary, J. A., Elenbass, J. R. and Weinang, C. F., 1959. Handbook of Natural Gas Engineering. New York (McGraw-Hill), 802 pp.

Langseth, M. G., Jr. and von Herzen, R. P., 1970. Heat flow through the floor of the world oceans. In The Sea. A. E. Maxwell (Ed.). New York (Wiley), 4, 299.

Markl, R. G., Bryan, G. M. and Ewing, J. L., 1970. Structure of the Blake-Bahama Outer Ridge. $J$. Geophys. Res. 75(24), 4539.
Peterson, M. N. A., Edgar, N. T., Cita, M., Gartner, S., Goll, R., Nigrini, C. and von der Borch, C., 1970. Initial Reports of the Deep Sea Drilling Project, Volume II. Washington (U.S. Government Printing Office), $490 \mathrm{pp}$.

Pitman, W. C., III and Talwani, M. (in press). Sea floor spreading in the North Atlantic. Bull. Geol. Soc. Am.

Saito, T., Burckle, L. H. and Ewing, M., 1966. Lithology and paleontology of the reflective layer Horizon A. Science. 154(3753), 1173.

Stoll, R. D., Ewing, J. and Bryan, G. M., 1971. Anomalous wave velocities in sediments containing gas hydrates. J. Geophys. Res. 76(8), 2090.

Windisch, C. C., Leyden, R. J., Worzel, J. L., Saito, T. and Ewing, J., 1968. Investigation of Horizon Beta. Science, 162(3861), 1473.

Winterer, E. L., Ewing, J., Schlanger, S. O., Moberly, R. M., Lancelot, Y., Jarrard, R. D., Douglas, R. G., Moore, T. C. and Roth, P., 1971. Deep Sea Drilling Project, Leg 17. Geotimes. 16(9), 12. 